\title{
URGENSI MANAJEMEN PENDIDIKAN PESANTREN DALAM KELUARGA
}

\author{
Miftah Wangsadanureja \\ Dosen STT Pelita Bangsa Bekasi \\ e-mail: miftahwangsa@pelitabangsa.ac.id \\ Received: 19-07-2018, Accepted: 25-07-2018, Published:30-07-2018
}

\begin{abstract}
The many cases of unethical learners of teachers have become a phenomenon today. Unfortunately this is not only happening in school alone, but in the boarding school environment that should reflect the educational institutions that form the character of human noble character. The question is the wrong management of pesantren education so far? Or is education in the family not in line with education in pesantren? This reality encourages the author to analyze the phenomenon, why the management of Islamic education in formal education institutions have not been able to change the character and morals of the students, so the authors consider that an important factor in facing this challenge is the need for Islamic education management in the family, primary education has a major influence in fostering and printing human character, while pesantren or other formal educational institution in essence as a means of support. A false mindset if every parent thinks pesantren as a "magic place" that will turn their children into good, when it will not happen when there is no cooperation between formal education management and family education management. The author wants to put forward the idea of the concept of the importance of presenting pesantren management at home, so that when the child enters into the world of boarding school has been accustomed to education at home.
\end{abstract}

\begin{abstract}
Abstrak
Banyaknya kasus peserta didik yang tidak beretika terhadap guru sudah menjadi sebuah fenomena saat ini. Sayangnya hal tersebut bukan hanya terjadi di sekolah saja, melainkan di lingkungan pondok pesantren yang seharusnya mencerminkan lembaga pendidikan yang membentuk karakter manusia berakhlak mulia. Yang menjadi pertanyaan adalah salahkah manajemen pendidikan pesantren selama ini? Atau apakah pendidikan dalam keluarga tidak sejalan dengan pendidikan di pesantren? Realitas ini mendorong penulis untuk menganalisis fenomena tersebut, mengapa manajemen pendidikan Islam di lembaga pendidikan formal belum mampu merubah karakter dan akhlak para peserta didiknya, sehingga penulis menganggap bahwa faktor penting dalam menghadapi tantangan ini adalah harus adanya manajemen pendidikan Islam dalam keluarga, sebab keluarga merupakan lembaga pendidikan utama yang berpengaruh besar dalam membina dan mencetak manusia berkarakter, sedangkan pesantren atau lembaga pendidikan formal lainnya pada hakikatnya sebagai sarana penunjang. Sebuah mindset yang salah jika setiap orangtua menganggap pesantren sebagai "tempat sulap" yang akan merubah anakanaknya menjadi baik, padahal semua itu tidak akan terjadi manakala tidak ada kerjasama antara menejemen pendidikan formal dengan menejemen pendidikan
\end{abstract}


keluarga. Penulis ingin mengemukakan gagasan tentang konsep mengenai pentingnya menghadirkan manajemen pesantren di rumah, sehingga ketika sang anak masuk ke dunia pesantren sudah terbiasa dengan pendidikan di rumahnya.

Keywords: Islamic education, participation, management of pesantren.

\section{PENDAHULUAN}

Fenomena pemukulan guru yang dilakukan oleh peserta didik akhir-akhir ini menjadi sebuah berita yang sering muncul ke permukaan. Sayangnya kejadian itu bukan hanya terjadi di lingkungan pendidikan umum saja, melainkan di lembaga-lembaga yang berlandaskan agama atau pesantren pun hal semacam itu kerap terjadi, hal ini tetap harus dikritisi sebab mereka adalah calon-calon da'i yang akan menjadi agen-agen kebaikan di lingkungan masyarakatnya, jadi wajar jika mereka harus ditempa sedikit berbeda dengan anak-anak umum lainnya.

Penulis ingin sedikit memberikan gambaran adanya beberapa pelanggaran santri yang tidak beretika, di antaranya adalah kurang baiknya santri kepada gurunya ketika berkomunikasi baik secara verbal atau nonverbal, atau ada juga santri yang suka mencuri barang teman-temannya dan yang lainnya. Sebagai praktisi di lapangan yang terjun langsung di dunia pesantren penulis bukan bermaksud ingin membuka aib sendiri melainkan hal ini justru yang harus diselesaikan bersama. Bahwa tugas mendidik itu bukan hanya dibebankan kepada para ustadz atau sistem yang ada di pesantren saja melainkan harus ada kerjasama di antara kedua belah pihak, yaitu pihak pesantren dan pihak keluarga.

Untuk mengetahui bagaimana keadaan pendidikan agama yang ada pada keluarga para santri, penulis mengadakan kuesioner terhadap 21 santri Ma'had Al-Ghorowi Bogor. Hasil dari kuesioner tersebut menunjukkan data sebagai berikut:

Tabel 1.

Data Keadaan Pendidikan Agama dalam Keluarga dan Motivasi Masuk Pondok Pesantren

\begin{tabular}{|l|l|l|l|}
\hline No & Nama Santri & $\begin{array}{l}\text { Keadaan Pendidikan Agama } \\
\text { dalam Keluarga }\end{array}$ & $\begin{array}{l}\text { Motivasi Masuk } \\
\text { Pondok Pesantren }\end{array}$ \\
\hline 1 & Santri 1 & Baik & Keinginan Sendiri \\
\hline 2 & Santri 2 & Baik & Keinginan Sendiri \\
\hline 3 & Santri 3 & Kurang & Keinginan sendiri \\
\hline 4 & Santri 4 & Biasa-biasa saja & Keinginan sendiri \\
\hline
\end{tabular}




\begin{tabular}{|l|l|l|l|}
\hline 5 & Santri 5 & Baik & Keinginan Sendiri \\
\hline 6 & Santri 6 & Baik & Keinginan Sendiri \\
\hline 7 & Santri 7 & Baik & Keinginan Sendiri \\
\hline 8 & Santri 8 & Kurang & Keinginan Sendiri \\
\hline 9 & Santri 9 & Kurang & Dorongan Orangtua \\
\hline 10 & Santri 10 & Baik & Keinginan Sendiri \\
\hline 11 & Santri 11 & Biasa-biasa saja & Keinginan Sendiri \\
\hline 12 & Santri 12 & Baik & Dorongan Saudara \\
\hline 13 & Santri 13 & Baik & Keinginan Sendiri \\
\hline 14 & Santri 14 & Baik & Dorongan keluarga \\
\hline 15 & Santri 15 & Kurang & Keinginan Sendiri \\
\hline 16 & Santri 16 & Baik & Keinginan Sendiri \\
\hline 17 & Santri 17 & Biasa-biasa saja & Keinginan Sendiri \\
\hline 18 & Santri 18 & Baik & Keinginan Sendiri \\
\hline 19 & Santri 19 & Biasa-biasa saja & Keinginan Sendiri \\
\hline 20 & Santri 20 & Biasa-biasa saja & Keinginan Sendiri \\
\hline 21 & Santri 21 & Baik & Keinginan Sendiri \\
\hline & & & \\
\hline
\end{tabular}

Dari tabel di atas menunjukkan data keluarga yang memperhatikan masalah agama adalah 12 orang sedangkan kategori keluarga yang kurang memperhatikan masalah agama adalah 9 orang. Alasan atau motivasi masuk pondok pesantren dengan keinginan sendiri dari keluarga yang baik pendidikan agamanya adalah 10 orang, dan 2 orang sisanya atas dorongan keluarganya. Sedangkan alasan atau motivasi masuk ponpes dari keluarga yang kurang baik dalam pendidikan agamanya adalah 8 orang dan hanya satu orang atas dasar dorongan keluarga. Dari data di atas hampir rata-rata santri yang masuk pesantren karena alasan keinginan sendiri lebih banyak dari pada santri yang masuk pesantren karena dorongan dari keluarga.

Setelah melakukan pengamatan beberapa bulan dan mendata beberapa pelanggaran yang dilakukan oleh santri, terdapat data sebagai berikut:

Tabel 2.

Data Pelanggaran Santri Ma'had Al-Ghorowi Angkatan 2017/2018

\begin{tabular}{|l|l|l|l|l|}
\hline No & $\begin{array}{l}\text { Santri } \\
\text { yang } \\
\text { Melangar }\end{array}$ & Pelanggaran & $\begin{array}{l}\text { Jenis } \\
\text { Pelanggaran }\end{array}$ & Tindakan \\
\hline 1 & Santri 1 & $\begin{array}{l}\text { 1. Memicu perkelahian } \\
\text { 2. Tidak sholat } \\
\text { berjamaah (asar) } \\
\text { 3. Merendahkan guru } \\
\text { 4. Menggunakan HP jam } \\
\text { OB pada jam } \\
\text { KBM/Tahfizh } \\
\text { 5. Keluar tanpa izin dari }\end{array}$ & Berat & Berat \\
\hline
\end{tabular}




\begin{tabular}{|c|c|c|c|c|}
\hline & & waktu dzuhur-asar & Berat & \\
\hline 2 & Santri 4 & $\begin{array}{l}\text { 1. Tidak mengumpulkan } \\
\text { HP } \\
\text { 2. Menyalahgunakan } \\
\text { perizinan }\end{array}$ & $\begin{array}{l}\text { Ringan } \\
\text { Sedang }\end{array}$ & Teguran Lisan \\
\hline 3 & Santri 9 & $\begin{array}{l}\text { 1. Tidak mengumpulkan } \\
\text { HP } \\
\text { 2. Menyalahgunakan } \\
\text { perizinan }\end{array}$ & $\begin{array}{l}\text { Ringan } \\
\text { Sedang }\end{array}$ & Teguran Lisan \\
\hline 4 & Santri 2 & $\begin{array}{l}\text { 1. Tidak mengumpulkan } \\
\text { HP }\end{array}$ & Sedang & Teguran Lisan \\
\hline 5 & Santri 20 & $\begin{array}{ll}\text { 1. Menggunakan } & \mathrm{HP} \\
\text { pada saat KBM } & \\
\end{array}$ & Berat & $\mathrm{SP} 1$ \\
\hline 6 & Santri 6 & $\begin{array}{ll}\text { 1. Menggunakan } & \mathrm{HP} \\
\mathrm{OB} \text { pada } & \text { jam } \\
\mathrm{KBM} / \mathrm{Tahfizh} & \end{array}$ & Sedang & Teguran Lisan \\
\hline 7 & Santri 8 & $\begin{array}{l}\text { 1. Kurang } \\
\text { memperhatikan } \\
\text { adab dan etika }\end{array}$ & Sedang & Teguran Lisan \\
\hline
\end{tabular}

Penulis mengambil sampel 7 orang santri yang melanggar dengan dua kategori, yaitu pelangaran sedang dan berat. Dari data tersebut santri yang melangggar dalam kategori sedang sebanyak 5 orang santri yang berasal dari keluarga yang kurang memperhatikan agama. Sedangkan santri yang melanggar peraturan berjenis pelanggaran berat ada 2 orang, satu orang berasal dari keluarga yang kurang memperhatikan masalah agama dan satu orang lagi berasal dari keluarga yang baik dalam masalah agamanya tetapi ternyata justru santri ini lah yang sering melanggar pelangaran berat sehingga diambil sebuah tindakan untuk mengeluarkannya dari pesantren.
Dari permasalahan di atas, sekiranya dapat di ambil sebuah kesimpulan sementara bahwa santri yang berasal dari keluarga yang kurang memperhatikan agama sering melanggar peraturan di pesantren. Akan tetapi, hipotesis ini pun belum diangap benar sebab ternyata dari 2 orang santri yang melanggar peraturan dengan kategori pelanggaran berat salah satunya berasal dari keluarga yang baik dalam masalah agamanya. Dari sini timbul pula hipotesis yang lainnya bahwa, tidak semua santri yang berasal dari keluarga yang baik dalam masalah agamanya akan baik pula di luar rumahnya, oleh karena itu tetap saja diperlukan adanya kontrol yang ketat berupa manajemen pendidikan 
Islam yang diterapkan dalam keluarga tersebut.

Oleh karena itu, dalam artikel sederhana ini penulis ingin mencoba membuat sebuah gagasan tentang konsep pendidikan keluarga dengan menajemen pendidikan pesantren. Sehingga ketika sang anak memasuki dunia pesantren dia sudah siap dan menerima segala bentuk disiplin yang diterapkan serta menjalankan peraturan dengan penuh kesadaran dirinya sendiri.

\section{TINJAUAN PUSTAKA}

\section{Pendidikan Islam dalam Keluarga}

Sejarah pendidikan Islam tidak terlepas dari sejarah awal mula dakwah Islam itu sendiri. Rasulullah S.A.W. sebagai pengemban amanah dakwah ini telah memulai mengajarkan pendidikan Islam dari lingkungan keluarganya, yaitu mulai dari Istrinya kemudian paman-pamannya. Dari sini pula lah konsep pendidikan islam dalam keluarga muncul yang diperkuat oleh firman Alloh S.W.T.:

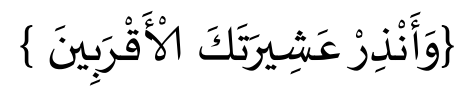

Artinya: "Dan berilah peringatan kepada kerabatkerabatmu yang terdekat." (QS. Asy Syu'ara [26]: 214).
Makna kerabat dalam "Kamus Besar Bahasa Indonesia" adalah pertalian keluarga yang memiliki hubungan sedarah sedaging. Sedangkan dalam "Kamus Bahasa Aَشيَير Arab-Indonesia Al-Munawir" kata diambil dari kata عاشره yaitu عشر ya yang artinya bergaul, berteman dengan. Jika dimasukkan ke dalam pola إفتَعَلَ maka akan berubah menjadi إعنَشَرَ yang artinya bergaul satu dengan yang lainnya (Al-Munawir, 1997: 933). Dan tempat yang sering kita bergaul di dalamnya adalah keluarga.

Oleh karena itu, pendidikan dalam keluarga sangat ditekankan, apalagi sebagai keluarga muslim maka pertama kali yang harus diterapkan adalah pendidikan agama Islam. Dalil yang lain yaitu dalam Surat At-Tahrim Ayat 6 memperjelas kepada kita bahwa setiap kita memiliki tanggung jawab untuk mengatur urusan agama dalam keluarganya yaitu menjaga diri dan keluarga dari ancaman siksa api neraka. Inilah inti dari tujuan pendidikan Islam dalam keluarga yaitu menanamkan keimanan kepada Allah Subhanahu Watala', sedangkan perkara Surga dan Neraka adalah perkara yang hanya bisa diyakini oleh keimanan kita kepada-Nya.

Hal ini senada dengan pendapat Moh. Solikodin Djaelani (2013: 101) 
yang mengatakan bahwa, pendidikan harus mengutamakan pendidikan keimanan. Sejarah telah membuktikan bahwa pendidikan yang tidak atau kurang memperhatikan pendidikan keimanan akan menghasilkan lulusan yang kurang baik akhlaknya. Akhlak yang rendah itu akan sangat berbahaya bagi kehidupan bersama yang dapat menghancurkan sendisendi kehidupan berbangsa dan bernegara. Lulusan sekolah yang kurang kuat imannya akan sangat sulit menghadapi kehidupan pada zaman yang semakin penuh tantangan di masa mendatang.

Selain memiliki tujuan inti tersebut, secara umum pendidikan Islam dapat dijabarkan kedalam beberapa tujuan lainnya. Menurut Muhammad Athiya Al-Abrasyi dalam Hasnindar Karim menyebutkan ada 5 tujuan pendidikan Islam, yaitu: 1) Pembentukan moral yang tinggi karena pendidikan Islam, tanpa mengabaikan pendidikan jasmani, akal dan ilmu praktis; 2) Mempersiapkan dan membekali anak untuk menatap kehidupan di dunia dan di akhirat; 3) Menumbuhkan dan mengembangkan segala aspek-aspek yang dapat memberikan manfaat; 4) Memberikan dan menumbuhkan kiat dan semangat ilmiah dengan mengkaji berbagai IImu demi kepentingan ilmu itu sendiri; dan 5) Memberikan bekal keterampilan profesional untuk kelangsungan hidup sebagai modal mencari nafkah. (Karim: 2012: 127)

Melihat dari tujuan pendidikan Islam di atas, terutama poin satu menjadi isyarat dan petunjuk bahwa tantangan pendidikan Islam pada masa yang akan datang adalah menyiapkan generasi yang santun, beretika dan bermoral sesuai dengan aturan Islam. Hal ini sependapat dengan salah seorang peneliti modern, yaitu Sholih Ali Abu Arrad yang memiliki perhatian kepada karya ilmiah dan penelitian di bidang pendidikan Islam, berpendapat bahwa pendidikan islam adalah penumbuhan pemikiran manusia, dan kerapian karakternya, dan emosionalnya di atas dasar-dasar agama Islam (Abu Arrad, 2015: 33).

Oleh karena itu diperlukan adanya sebuah manajeman untuk mengatur bagaimana tujuan pendidikan Islam itu dapat tercapai, salah satunya adalah dengan cara menerapkan manajemen ala pesantren di dalam keluarga, sebab 'keluarga menjadi peran utama dan sangat penting dalam menjaga keberadaan anak dan sebagai lembaga pendidikan yang paling dominan secara mutlak' (Alam, 2016: 163). 


\section{Manajemen Pesantren}

Jika dilihat dari segi susunan kalimat, maka "manajemen pesantren" terdiri dari dua suku kata, yaitu manajemen dan pesantren. Sebelum kita mendefinisikan apa itu manajemen pesantren maka terlebih dahulu kita harus mengetahui makna dari kedua suku kata tersebut.

Secara etimologis, pengertian manajemen merupakan seni untuk melaksanakan dan mengatur. Manajemen ini juga dilihat sebagai ilmu yang mengajarkan proses mendapatkan tujuan dalam organisasi, sebagai usaha bersama dengan beberapa orang dalam organisasi tersebut (www.jurnal.id pengertianfungsi-dan-unsur-unsur-manajemen diakses pada hari Sabtu 2018).

Manajemen suatu ilmu atau seni yang dimiliki oleh seorang pemimpin (leader) dalam upaya memanfaatkan sumber-sumber daya organisasi yang ada melalui kegiatan perencanaan, pengorganisasian, pelaksanaan, dan pengawasan serta dilakukan dengan melibatkan partisipasi seluruh komponen menurut fungsinya masing-masing dalam rangka mencapai tujuan organisasi secara efektif dan efisien. (Yahya:2015:97)

Sedangkan istilah pesantren merujuk pada tempat belajar bagi kaum intelektual Muslim yang dinamakan santri. Mereka mewarisi dan memelihara keberlanjutan tradisi keilmuan Islam sehingga sampai kepada dakwah Rasulullah S.A.W. (khazanah.republika. co.id). Begitupula menurut Daulay dalam Yahya bahwa pesantren mempunyai arti tempat orang berkumpul untuk belajar agama Islam (Yahya: 2015).

Dari segi sistem pendidikan pesantren tidak terlepas dari 3 figur utama, yaitu adanya kiyai, ustadz, dan santri. Untuk segi tempat pengajaran dan kegiatan pembelajarannya dalam lingkungan pesantren berputar sekitar masjid, asrama, dan kelas. Masjid sebagai sarana vital dalam pesantren, sebab selain digunakan sebagai tempat ibadah terkadang masjid juga digunakan sebagai sarana transformasi ilmu dari sang kiyai atau stafnya kepada para peserta didiknya. Tempat kedua setelah masjid adalah asrama, yaitu tempat para santri bergaul dengan sesama rekannya istilah ini sering disebut muamalah, di sinilah para santri dididik menjadi makhluk sosial dan sebagai tempat untuk membina rasa persaudaraan diantara mereka juga menumbuhkan sikap kemandirian.

Sedangkan untuk pola kurikulum yang ada dalam pesantren biasanya lebih kepada ilmu-ilmu pendidikan 
agama, seperti akidah, fiqih, akhlak, dan bahasa Arab. Selain itu pesantren pun memiliki sistem administratif tersendiri, yaitu proses pembiayaan selama santri mondok di pesantren tersebut.

Dari beberapa pengertian di atas, tentunya kita dapat mensintesis bahwa makna manajemen pesantren adalah sebuah upaya pengorganisasian untuk berlangsungnya kegiatan-kegiatan keagamaan yang terbina, terbimbing, dan terkontrol di dalam sebuah lingkungan pesantren untuk mencapai tujuan pendidikan Islam.

Tujuan pendidikan Islam sebagaimana yang telah disebutkan sebelumnya pada intinya adalah untuk membentuk jiwa seseorang yang berbudi luhur dengan landasan keimanan dan ketakwaan kepada Alloh S.W.T. serta dibina untuk menjadi manusia mandiri yang siap bersaing dan bertahan di tengah-tengah kehidupan dunia ini tanpa harus bergantung pada pertolongan orang lain, usaha dan tawakal menjadi bekal hidup utama dalam mengarungi kehidupannya nanti.

\section{Penerapan Manajemen Pendidikan Pesantren dalam Keluarga} Penerapan manajemen pendidikan pesantren yang dimaksudkan oleh penulis disini adalah sebuah konsep teknis pembelajaran pesantren atau kegiatan pesantren yang diterapkan di dalam rumah. Sebagaimana yang telah disinggung di atas, bahwa konsep manajemen pendidikan pesantren yang kemudian diterapkan dalam pendidikan keluarga ini penulis mengacu kepada pola pendidikan yang ada di pondok pesantren secara global, berikut pola pendidikan pesantren yang diterapkan pada pendidikan keluarga

\section{Manajemen SDM (Sumber Daya Manusia) dalam Rumah ala konsep Pesantren}

a. Orangtua berperan sebagai kiyai, ustadz/ustadzah

Yang pertama kali yang harus diterapkan pada konsep pendidikan rumah berbasis pendidikan pesantren ini adalah peran orangtua sebagai pendidik sekaligus pengatur kegiatan pendidikan yang ada di dalam rumahnya. Orangtua harus berperan sebagai Kiyai sekaligus pengajar bagi anak-anaknya. Seorang ayah bisa diangkat menjadi seorang kiyai dalam rumahnya, artinya dia harus belajar agama lebih mendalam lagi, sebab selain dia akan menjadi figur yang akan dicontoh oleh penghuni dalam keluarganya memperdalam ilmu agama merupakan kewajiban dia sebagai 
seorang muslim. Hal ini untuk mengimplementasikan Ayat Al-Quran sebagaimana yang tertuang dalam Surat At-Tahrim Ayat yang keenam.

Demikian juga peran seorang lbu yang tidak kalah penting dari peran ayah. Justru dalam hal pendidikan sepertinya ibu memilki jam mengajar yang lebih dibandingkan dengan bapak. Sebab ibulah yang lebih dekat dengan anak-anaknya, lebih banyak waktu berada dalam rumah dibandingkan ayah. Oleh karena itu, seorang ibu juga harus lebih giat memperdalam ilmu agama yang akan disampaikan kepada anak-anaknya. Maka sangatlah wajar jika ada sebuah ungkapan Arab "al-Ummu MadrasatulUla”, seorang ibu adalah madrasah pertama bagi anak-anaknya.

\section{b. Anak berperan sebagai santri/santriwati}

Setelah adanya pak Kiyai yang akan memenej kehidupan rumahnya dengan nilai-nilai islami dan seorang ibu pendidik, maka harus ada objek yang akan dididik. Objek pendidikan tersebut adalah anak. Seorang anak harus berperan menjadi seorang santri atau santriwati yang harus siap menerima pembelajaran dan sistem pendidikan Islam yang ada dalam rumahnya.
Walau demikian, memposisikan anak sebagai perserta didik bukan berarti harus memperlakukan mereka dengan kekerasan, adapun adanya dalil Rasulullah shallallaahu 'alaihi wa sallam yang bersabda:

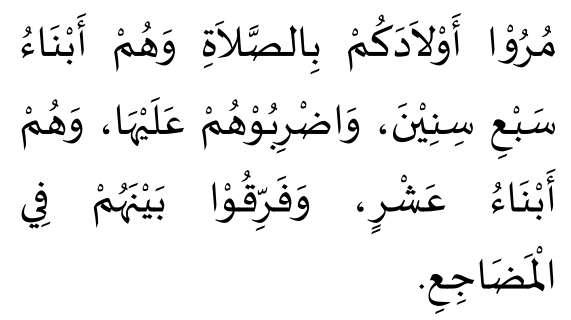

"Suruhlah anak kalian shalat ketika berumur 7 tahun, dan kalau sudah berusia 10 tahun meninggalkan shalat, maka pukullah ia. Dan pisahkanlah tempat tidurnya (antara anak laki-laki dan anak wanita)." (Hadits hasan: Diriwayatkan oleh Abu Dawud (no. 495), Ahmad (II/180, 187) dengan sanad hasan, dari 'Amr bin Syu'aib, dari ayahnya, dari kakeknya radhiyallaahu ‘anhum.

Pukulan yang dimaksud di sini adalah bukan pukulan yang menyakitkan, seperti melukai kulit atau mematahkan tulang. Hal ini sebagaimana sabda Nabi S.A.W. lainnya, dari Abu Burdah Al-Anshari, 
dia mendengar Rasulullah shallallahu alaihi wa sallam bersabda, "Seseorang tidak boleh dipukul lebih dari sepuluh kali kecuali dalam masalah hudud (hukuman tetap) dari Allah Ta'ala." (HR. Bukhari, no. 6456, Muslim, no. 3222).

Ibnu Qayyim rahimahullah berkata, "Sabda Rasulullah shallallahu alaihi wa sallam, 'Tidak boleh memukul lebih dari sepuluh kali kecuali dalam masalah hudud' maksudnya dalam hal jinayat (pidana kriminal seperti mencuri, dan lai-lain) yang merupakan hak Allah. (www.islamqa.info.id diakses pada hari Kamis 12 April 2018)

\section{Manajemen Lingkungan Islami dalam Keluarga}

Lingkungan merupakan salah satu elemen penting dalam proses pelaksanaan pendidikan. Tentu saja, lingkungan pendidikan yang kondusif, aman, nyaman akan sangat mendukung terselenggaranya tujuan pendidikan yang diharapkan oleh semua pihak, baik oleh orang tua, guru/pendidik, masyarakat dan bahkan oleh pemerintah sebagai pemangku kebijakan penyelenggaraan sistem pendidikan nasional, dimana salah satu tujuannya adalah membangun manusia-manusia Indonesia yang beriman, bertaqwa, barkarakter, berpengetahuan, sehat jasmani dan rohani (Ginanjar, M.H. 2017).

Demikian pula dalam sistem pendidikan Islam, lingkungan harus didesain sedemikian rupa disesuaikan dengan karakteristik pendidikan Islam itu sendiri. Dalam literatur pendidikan, lingkungan biasanya disamakan dengan institusi atau lembaga pendidikan. Meskipun kajian ini tidak dijelaskan dalam Al-Qur'an secara eksplisit, akan tetapi terdapat beberapa isyarat yang menunjukkan betapa pentingnya pemilihan lingkungan pendidikan tersebut. Oleh karenanya, dalam kajian pendidikan Islam, lingkungan pendidikan tersebut mendapat perhatian utama (Ginanjar, M.H. 2017).

Terkait dengan pentingnya lingkungan pendidikan Islami, maka hal utama yang perlu diprioritaskan adalah penyiapan dan pengembangan sumber daya manusia (SDM), baik itu pendidik yang profesional maupun orangtua sebagai pendidik secara kodrati. Setelah menyiapkan SDM ini, langkah selanjutnya adalah menciptakan lingkungan yang Islami dalam keluarga seperti pola lingkungan pesantren, salah satunya adalah dengan langkahlangkah sebagai berikut ini: 
a. Menjadikan Rumah Sebagai ruang untuk belajar agama, Pondok Pesantren mempelajari serta berdiskusi

Lingkungan pendidikan yang tentangnya. Adanya tempat baca bukupertama dikenal oleh anak dalam menanamkan nilai-nilai pendidikan adalah lingkungan keluarga. Kedua orangtua-nya adalah pemain peran ini, Orangtua berkewajiban memberikan perhatian (Ginanjar, M.H. 2013: 379). Lingkungan keluarga adalah sebuah basis awal kehidupan bagi setiap manusia. Banyak hadits yang meriwayatkan pentingnya pengaruh keluarga dalam pendidikan anak dalam beberapa masalah seperti masalah akidah, budaya, norma, emosional, dan sebagainya. Rumah bukan hanya sebatas tempat untuk berlindung dari teriknya panas matahari dan derasnya hujan saja, akan tetapi rumah juga bisa dijadikan sebagai tempat pendidikan. Menciptakan suasana pesantren dalam rumah ternyata suatu perkara yang sudah diisyaratkan oleh Rasulullah S.A.W. melalui hadits-haditsnya yang mulia. Lihat saja dalil yang telah dikutip di atas tentang adanya pemisahan kamar antara anak laki-laki dan anak perempuan. Dalam lingkungan pesantren hal ini sudah diterapkan, yaitu adanya asrama laki-laki dan asrama perempuan.

Selain pemisahan kamar, pilihlah salah satu ruangan sebagai buku keagamaan, atau bisa kita sebut sebagai perpustakaan pribadi dalam rumah yang dimana di dalamnya terdapat rak berisi buku-buku keagamaan.

Untuk pelaksanaan sholat lima waktu, khusus anak laki-laki adalah di masjid, jadi seorang ayah mengajak anak laki-lakinya untuk sholat berjamaah di masjid yang terletak di lingkungan sekitar rumahnya, bukan mushola yang ada di dalam rumahnya. Biarkan tempat ini digunakan oleh anggota keluarga yang perempuan saja. Atau jika ada kendala syari yang dapat menghalangi seorang lelaki pergi ke masjid seperti hujan lebat, sakit dan semisalnya, maka sholat berjamaah bersama anggota keluarga tidaklah mengapa.

b. Kontroling Kegiatan Ibadah Anggota Keluarga

Sekali lagi penulis sampaikan bahwa menciptakan manajemen pesantren di dalam rumah yang digagas pada tulisan ini adalah terbatas pada manajemen pendidikan Islam secara global, yaitu seperti penekanan sholat lima waktu, mempelajari ilmu-ilmu agama serta 
ibadah lainnya. Kegiatan-kegiatan ibadah seperti itu perlu adanya kontroling yang ekstra dari kedua orangtua sebagai pelaksana manajemen Islami di dalam rumahnya.

Instrumen yang dapat digunakan pada kontroling ini adalah sebuah tabel harian yang diberikan kepada seluruh anggota keluarga. Berikut ini adalah salah satu contoh tabel harian ibadah sehari-hari.

Tabel 3.

Contoh Kegiatan Ibadah Harian

\begin{tabular}{|l|l|l|l|l|l|l|l|l|l|l|}
\hline \multirow{2}{*}{ No } & \multicolumn{1}{|c|}{ Kegiatan } & \multicolumn{7}{|c|}{ Tanggal } & Ket \\
\hline & & 1 & 2 & 3 & 4 & 5 & 6 & 7 & 30 & \\
\hline 1 & Sholat Subuh Berjamaah & & & & & & & & & \\
\hline 2 & Sholat Dzuhur Berjamaah & & & & & & & & & \\
\hline 3 & Sholat Ashar Berjamaah & & & & & & & & & \\
\hline 4 & Sholat Magrib Berjamaah & & & & & & & & & \\
\hline 5 & Sholat Isya Berjamaah & & & & & & & & & \\
\hline 6 & Membaca Alqur'an & & & & & & & & & \\
\hline 7 & Shaum Sunnah Senin & & & & & & & & & \\
\hline 8 & Shaum Sunnah Kamis & & & & & & & & & \\
\hline 9 & Membaca Buku Agama & & & & & & & & & \\
\hline 10 & Dzikir Pagi & & & & & & & & & \\
\hline 11 & Dzikir Sore & & & & & & & & & \\
\hline 12 & $\begin{array}{l}\text { Berkata Baik dan Tidak } \\
\text { Berbohong }\end{array}$ & & & & & & & & \\
\hline 13 & Membantu Orangtua & & & & & & & & & \\
\hline 14 & Ibadah lainnya & & & & & & & & & \\
\hline
\end{tabular}

Kegiatan pada tabel di atas adalah salah satu contoh ibadah harian yang umum. Tabel ibadah harian ini diceklis oleh sang anak kemudian dikumpulkan setiap harinya menjelang tidur kepada ayah atau Ibunya. Setelah seminggu atau sebulan diadakan evaluasi terkait ibadah mereka, jika misalnya dalam seminggu ini sholat berjamaahnya kurang berarti ibadah sholat si anak perlu diperhatikan lagi, demikian juga pada ibadah yang lainnya.
Adapun konten ibadah yang akan ditingkatkan sesuai dengan misi dan visi keluarga itu sendiri, contohnya jika keluarga tersebut berorentasi menjadi keluarga penghafal AI-Qur'an maka pada tabel ibadah ditambahkan kembali poin hafalan Al-Qura'n-nya.
c. Mempersiapkan Pendidikan Islami Bagi Anak

Diakui atau tidak, pendidikan Islami secara total yang akan diterapkan dalam keluarga memang sesuatu yang tidak mudah, akan tetapi 
dengan menerapkan konsep diatas setidaknya hal ini akan sedikti membantu setiap orangtua untuk menyiapkan anak-anaknya yang berdisiplin serta taat terhadap ajaran agama.

Oleh karena itu dibutuhkan bantuan dari pihak lain untuk menambah pengetahuan wawasan keagamaan anak-anak kita. Yang pertama adalah dengan memanggil guru agama ke rumahnya untuk belajar ilmu-ilmu agama yang benar. Hal ini sering kita abaikan, terkadang kita lebih memfokuskan pendidikan anak-anak kita dalam urusan masalah duniawi saja, seperti privat bahasa Inggris, matikmatika, dan lainnya. Hal ini bukan berarti tidak boleh, akan tetapi maksud penulis di sini seharusnya diimbangi juga dengan menghadirkan guru privat agama.

Yang kedua, adalah dengan cara menyekolahkan anak-anak ke lembaga-lembaga pendidikan Islam seperti SDIT, SMPIT, SMAIT ataupun pondok pesantren. Hal ini agar pendidikan Islam yang diterapkan di lingkungan keluarga akan lebih terpatri dalam jiwa anak dan adanya kesinambungan antara pendidikan luar rumah dengan pendidikan yang ada dalam rumah.
KESIMPULAN

Manajeman

pendidikan

pesantren yang diterapkan pada pendidikan keluarga setidaknya dapat mengurangi problematika pendidikan saat ini, yaitu kurang beretikanya peserta didik terhadap gurunya. Pendidikan keluarga adalah kunci utama dalam mendidik manusiamanusia yang beretika dan berahlak.

Dengan penerapan manajemen pesantren dalam pendidikan keluarga diharapkan bisa membentuk pribadipribadi muslim yang santun dan berbudi luhur, dimanapun mereka berada baik ditempat umum lebih-lebih ditempat yang baik dalam masalah agamya mereka akan menjadi contoh dan panutan bagi lingkungannya.

Laiknya sebuah pesantren, maka di dalam rumah harus hadir sesosok Kiyai dan pendidik yang handal, mereka itu adalah kedua orangtua. Ayah dan ibu memiliki peran yang besar dalam memenej pendidikan yang ada dalam rumahnya, hitam dan putihnya sebuah keluarga tergantung sistem manajemen yang diterapkannya. Oleh karena itu, wajib bagi setiap orangtua yang ingin menghadirkan suasana pesantren dalam rumahnya untuk mencari ilmu agama sebanyak-banyaknya. 


\section{Menciptakan}

manajemen

pesantren di dalam rumah yang digagas pada tulisan ini adalah terbatas pada manajemen pendidikan Islam secara global, yaitu seperti penekanan sholat lima waktu, mempelajari ilmu-ilmu agama serta ibadah lainnya. Kegiatan-kegiatan ibadah seperti itu perlu adanya kontroling yang ekstra dari kedua orangtua sebagai pelaksana manajemen islami di dalam keluarga

Menerapkan pendidikan Islami secara total yang akan dijalankan dalam keluarga memang sesuatu yang tidak mudah, akan tetapi dengan menerapkan konsep diatas setidaknya hal ini akan sedikti membantu setiap orangtua untuk menyiapkan anak-anaknya yang berdisiplin serta taat terhadap ajaran agama, berdedikasi serta beretika.

\section{DAFTAR PUSTAKA}

Adlin, M. (2016). "Tantangan Manajemen Pendidikan Islam Dalam Menghadapi Era Globalisasi." Jurnal_uinsu.ac.id.

Abu Arrad, Sholih Ali. (2015). Pengantar Pendidikan Islam. Bogor: Marwah Indo Media.

Alam, Lukis. (2016). "Aktualisasi Pendidikan Islam dalam Keluarga." Jurnal Muaddib. 06 (02).163.

Djaelani, Moh.Solikodin. (2013). "Peran Pendidikan Agama Islam dalam Keluarga dan Masyarakat." Jurnal IImiah Widya 1 (02).101.
Ginanjar, M. H. (2017). URGENSI LINGKUNGAN PENDIDIKAN SEBAGAI MEDIASI PEMBENTUKAN KARAKTER PESERTA DIDIK. Edukasi Islami: Jurnal Pendidikan Islam, 2 (04).

Jailani, M. Syahran. (2014). "Teori Pendidikan Keluarga dan Tanggung Jawab Orangtua dalam Pendidikan Anak Usia Dini." Nadwa Jurnal Pendidikan Islam. 08 (02).

Karim, Hasnidar. (2012). "Kepribadian Muslim dalam Pendidikan Agama." Al-'Ulum 1.

Kamus Al-Munawir. 14 ed. Surabaya: Pustaka Progresif, 1997.

Muklasin. (2016). "Manajemen Pendidikan Karakter Santri (Studi Kualitatif di Pondok Pesantren Bahrul 'Ulum Margodadi Kecamatan Sumberejo Kabupaten Tanggamus)." Tesis, Universitas Lampung.

Suharnis. (2015). Nilai-Nilai Pendidikan Islam Dalam Keluaraga Islam." Jurnal Musawa 07 (01). 52-79.

Tidjani, Aisyah. (2017). "Manajemen Lembaga Pendidikan Islam Menghadapi Tantangan Globalisasi." Jurnal Reflektika 13 (01).

Yahya, Fata Asyrofi. (2015). "Problem Manajemen Pesantren, Sekolah, Madrasah: Problem Mutu dan Kualitas Input-Proses-Output." Tarbawi Jurnal Pendidikan Islam. VIII, (01).

www.jurnal.id pengertian-fungsi-danunsur-unsur-manajemen diakses pada hari Sabtu 14 April 2018

www.islamqa.com diakses pada hari Sabtu 14 April 2018 